\title{
Da história à palavra: A teologia da revelação em Paul Ricoeur
}

\author{
Orientadora: Maria Clara Lucchetti Bingemer \\ Mestrando: Esdras Costa Bento \\ Área de Concentração: Teologia Sistemático-Pastoral
}

Linha de Pesquisa: Religião e Modernidade

A hermenêutica da ideia de revelação é um dos mais autênticos e originais trabalhos teológicos do filósofo francês Paul Ricœur. As duas propostas fundantes do autor apresentam um conceito de revelação que respeita as idiossincrasias próprias de cada gênero literário da Escritura e ao mesmo tempo dialoga com uma filosofia hermenêutica que proporciona uma autêntica dialética entre as verdades da fé e as verdades da razão. Assim, critica-se um conceito opaco e autoritário de revelação e reivindica-se um conceito polifônico, polissêmico e analógico de revelação. Os elementos teóricos que implementam o conceito ricœuriano de revelação são: "o mundo do texto", "a hermenêutica do distanciamento", "o discurso como evento e significação", "a categoria Poética" e "a hermenêutica do testemunho". Por meio dessa dialética viva pretende-se libertar o conceito de revelação das fórmulas dogmáticas e reconduzi-la à confissão de fé presentes nos discursos profético, narrativo, prescritivo, sapiencial e hínico. A opacidade maciça do conceito de revelação somente pode ser superada por intermédio de uma hermenêutica de revelação que respeite as expressões polifônicas originárias da revelação nas quais se baseiam a confissão de fé do povo de Deus.

Palavras-chave: Revelação; hermenêutica; mundo do texto. 